\title{
PERAN MASYARAKAT DALAM LEMBAGA PENDIDIKAN
}

\author{
Nurhasanah $^{1}$ \\ STAI Al-Amin Dompu
}

\begin{abstract}
Abstrak: Semangat desentralisasi pendidikan perlu disambut dengan baik oleh lembaga pendidikan yang mana lembaga pendidikan diberi kebebasan dalam mengelola lembaganya sesuai dengan kebutuhan masyarakat di sekitarnya dan melibatkan partisipasi masyarakat dalam menjalankan proses pendidikannya. Untuk mewujudkan ini tentu berbagai bidang di struktur organisasi lembaga sekolah difungsikan secara maksimal tidak hanya yang bersifat akademis yang saja yang diperhatikan tetapi juga yang bersifat pendukung dalam hal ini bidang humas yang menjadi mediator komunikasi antara lembaga pendidikan dengan masyarakat. Inilah yang belum disadari oleh lembaga pendidikan dan masyarakat dimana mereka masih menganggap dua bagian yang terpisahkan sehingga tidak adanya kepedulian terhadap keberadaan masing-masing, padahal mereka adalah dua kelompok yang tidak bisa dipisahkan dalam pelaksanaan proses pendidikan untuk menghasilkan akhlak generasi masyarakat yang bermoral.
\end{abstract}

Kata Kunci: Masyarakat, Lembaga Pendidikan

\section{Pendahuluan}

Di era modern ini persaingan pendidikan semakin meningkat dan berbagai strategi dilakukan untuk menarik perhatian masyarakat atau peminat dalam hal ini stakeholder eksternal agar agar memiliki antusias yang tinggi terhadap dunia pendidikan khususnya lembaga pendidikan. Untuk menarik perhatian masyarakat lembaga selalu berusaha untuk menjalin hubungan kerjasama yang baik dengan berbagai pihak termasuk di dalamnya masyarakat dengan melibatkan mereka dalam merumuskan pengelolaan lembaga pendidikan serta yang menjadi pemantau proses pendidikan.

Adanya keterkaitan antara lembaga pendidikan dengan masyarakat inilah yang masih belum disadari oleh kedua belah pihak, terutama masyarakat awam yang beranggapan bahwa mereka dengan lembaga pendidikan adalah lingkungan yang berbeda, padahal keterlibatan mereka sangat memberikan pengaruh yang positif bagi

\footnotetext{
${ }^{1}$ Dosen pada Program Studi Pendidikan Agama Islam (PAI) di STAI Al-Amin Dompu
} 
lembaga pendidikan. Di pihak lembaga pendidikan juga belum memberikan ruang gerak bagi masyarakat untuk ikut terlibat dalam proses pendidikan kalaupun ada hanya sebatas keterlibatan secara materi sedangkan secara fisik dan psikis belum dilibatkan secara maksimal.

Peluang besar bagi lembaga pendidikan dengan adanya desentralisasi pendidikan yang memberikan kebebasan bagi lembaga pendidikan untuk mengelola lembaganya sesuai dengan kebutuhan masyarakat di sekitarnya dan menjadi cikal bakal munculnya teori dan aplikasi manajemen berbasis sekolah (MBS) yang menuntut peran masyarakat secara maksimal di dalamnya. Dengan adanya kebijakan desentralisasi tersebut salah satu konsekuensi dalam penyelenggaraan pendidikan yang berbasis masyarakat adalah menanti keterlibatan masyarakat secara keseluruhan yaitu orangtua siswa, masyarakat sekitar sekolah, pengusaham organisasi social kemasyrakatan dan pemerintah dalam penyelenggara pendidikan. Oleh karena itu sekolah sebagai unit pelaksana pendidikan harus dapat menjalin kerjasama dengan masyarakat baik dari segi pemikiran, tenaga, pembiayaan serta pemecahan masalah yang dihadapi oleh lembaga pendidikan (Maisyaroh, 2011:116).

Dari segi edukatif dan psikologis lembaga pendidikan dan masyarakat saling memiliki kebutuhan yang sama dimana masyarakat membutuhkan tempat untuk menuntut ilmu dan lembaga pendidikan membutuhkan masyarakat untuk menuntut ilmu di lembaganya, karena adanya kecenderungan perubahan yang terus terjadi dalam pendidikan untuk menekan perkembangan pribadi dan sosial masyarakat. Perubahan yang terus terjadi inilah yang mengharuskan lembaga pendidikan untuk mengintegrasikan diri dengan masyarakat. Elsbree dalam Mulyono (2008:202) menyatakan ada tiga faktor yang menyebabkan lembaga pendidikan harus berhubungan baik dengan masyarakat, yaitu (1) faktor perubahan sifat, tujuan dan metode pengajaran di lembaga pendidikan, (2) faktor masyarakat yang menuntut adanya perubahan dalam pendidikan dan perlunya bantuan masyarakat terhadap lembaga pendidikan, (3) faktor perkembangan ide demokrasi bagi masyarakat terhadap pendidikan.

\section{Hubungan Lembaga Pendidikan dengan Masyarakat}

Lembaga pendidikan tidak dibenarkan untuk menutup diri dari masyarakat terutama masyarakat sekitarnya juga tidak wajar melaksanakan idenya sendiri dengan 
tidak mendengarkan atau melaksanakan aspirasi-aspirasi masyarakat karena pada hakikatnya lembaga pendidikan adalah milik masyarakat. Masyarakat menginginkan lembaga pendidikan berdiri di lingkungannya untuk meningkatkan perkembangan sumber daya manusianya, masyarakat juga menginginkan agar lembaga pendidikan bias memberikan pengaruh positif terhadap perkembangan masyarakat baik langsung maupun tidak langsung dengan harapan masyrakat pula turut mendukung usahausaha yang dilakukan oleh lembaga pendidikan di lingkungannya.

Lembaga pendidikan merupakan sistem terbuka bagi masyarakat, sebagai sistem yang terbuka sudah jelas tidak dapat mengisolasi diri serta penting untuk menyadari keberadaan masyarakat baik ide-idenya, kebutuhan-kebutuhannya serta nilai-nilai yang ada di masyarakat. Begitupun sebaliknya menyadari bahwa lembaga pendidikan sangat membantu mereka untuk menyiapkan SDM yang berkualitas tentu sesuai dengan keinginan mereka sendiri dengan tidak membiarkan lembaga pendidikan saja yang berperan aktif tetapi masyarakat juga karena bagaimanapun dalam membentuk manusia dewasa melalui proses pendidikan tidak akan bias terwujud tanpa dukungan dan kerjasama dari masyarakat. Pada hakekatnya lingkungan pendidikan itu ada tiga yang sangat erat kaitannya dan tidak bias berdiri sendiri, yaitu lingkungan pendidikan di keluarga, lingkungan pendidikan di lembaga pendidikan dan lingkungan pendidikan di masyarakat. Jadi, antara lembaga pendidikan dan masyarakat terjadi komunikasi dua arah untuk saling bias memberi dan saling menerima.

Komunikasi dua arah yaitu dari lembaga pendidikan ke masyarakat dan dari masyarakat ke lembaga pendidikan adalah untuk saling memberi informasi dan berpartisipasi dalam membina proses pendidikan. Pemikiran dalam pengembangan pendidikan tidak selalu harus datang dari lembaga pendidikan dan tidak menutup kemungkinan ide-ide dari masyarakat dapat diterapkan dalam proses pendidikan karena tidak semua program atau ide dari lembaga pendidikan sesuai dengan kebutuhan masyarakat. Hubungan komunikasi dua arah ini sangat efektif dalam pengembangan proses pendidikan apabila benar-benar diterapkan oleh kedua belah pihak. Ngalim Purwanto menyatakan bahwa kerjasama antara lembaga pendidikan dengan masyarakat digolongkan menjadi tiga jenis, yaitu: 
Hubungan edukatif, yaitu hubungan kerjasama antara lembaga pendidikan dan masyarakat dalam hal mendidik peserta didik, antara guru di lembaga pendidikan dan orangtua dalam keluarga. Kerjasama tersebut dapat direalisasikan dengan mengadakan pertemuan yang direncanakan secara periodik antara guru-guru dan orangtua peserta didik sebagai anggota komite sekolah

Hubungan kultural, yaitu kerjasama antara lembaga pendidikan dan masyrakat untuk membina dan mengembangkan kebudayaan masyarakat setempat karena bagaimanapun pendidikan merupakan bagian dari kebudayaan masyarakat sekitar. Untuk mewujudkan kerjasama ini yaitu dengan mengerahkan peserta didik untuk membantu kegiatan-kegiatan sosial yang diperlukan oleh masyarakat dengan bergotong-royong memperbaiki jalan, membersihkan lingkungan, menjaga kelestarian lingkungan dan juga bersama-sama menyelenggarakan perayaan yang bersifat keagamaan ataupun nasional.

Hubungan institusional, yaitu hubungan kerjasama antara lembaga pendidikan dengan lembaga atau instansi resmi lainnya baik swasta maupun pemerintah, misalnya hubungan lembaga pendidikan dengan puskesmas, pemerintah setempat, dinas-dinas, pasar dan sebagainya (Sri Minarti, 2011:278-280).

Abdul Hadis dan Nurhayati (2010:3) dalam bukunya Manajemen Mutu Pendidikan menyampaikan bahwa tanpa adanya kerjasama yang baik dengan berbagai pihak lembaga pendidikan tidak akan mampu berjalan sendiri dalam menjalankan proses belajar mengajar agar dapat menghasilkan peserta didik yang bermutu. Belum lagi tuntutan peningkatan mutu yang dilakukan oleh lembaga pendidikan. Salah satu merosotnya mutu pendidikan karena kurang memaksimalkan komunikasi dan informasi dalam dunia pendidikan termasuk di dalamnya menjalin hubungan kerjasama yang baik dengan masyarakat .

Selain itu pendidikan karakter yang marak diusung oleh para ahli pendidikan sekarang belum mencapai hasil yang maksimal sesuai harapan bersama, karena semakin merosotnya akhlak bangsa yang sering terlihat di berbagai media massa, ini juga karena tidak adanya keterlibatan masyarakat dalam mengawasi proses pendidikan. Seharusnya masyarakat tidak menyerahkan sepenuhnya tanggungjawab mendidik generasi ke lembaga pendidikan tetapi juga mereka mempunyai peran yang 
penting dalam hal ini, tentu dengan adanya komunikasi yang baik terlebih dahulu antara kedua belah pihak.

\section{Posisi Bidang Humas di Lembaga Pendidikan}

Bidang Humas di lembaga pendidikan sangat penting mengingat fungsinya sebagai mediator dalam mengembangkan kerjasama dengan masyarakat. Tetapi yang terjadi sekarang masih banyak lembaga pendidikan belum memfungsikan bidang Humas di lembaganya, bahkan meniadakan atau berbaur dengan bidang lain. Walaupun bidang tersebut dimasukkan dalam struktur organisasinya tetapi masih belum maksimal dalam melaksanakan fungsi dan tugas manajemennya, bisa dipastikan adanya saja bidang Humas di struktur kelembagaan masih belum melaksanakan fungsi manajemennya dengan apalagi ditiadakan sama sekali.

Dalam pengertiannya bidang Humas adalah sebagai fungsi manajemen yang khas, maka dalam penetapan fungsinya tidak terlepas dari fungsi manajemen itu sendir yaitu sebagai fungsi perencanaan, pengorganisasian, penggerakkan, pengkoordinasiaan, pengarahan dan fungsi pengawasan dalam konteks kegiatan di lembaga pendidikan (Tim Dosen UPI, 2009:11). Maka dari itu keberadaan bidang humas sangatlah penting baik bagi lembaga pendidikan itu sendiri juga bagi masyarakat. T Sianipar dan Purwanto mengemukakan tujuan bidang humas dilihat dari kepentingan kedua belah pihak yaitu lembaga pendidikan dan masyarakat bahwa dilihat dari kepentingan lembaga pendidikan tujuan bidang Humas yaitu:

1. Memelihara kelangsungan hidup lembaga pendidikan, meningkatkan mutu di lembaga pendidikan

2. Memperlancar proses belajar mengajar

3. Memperoleh dukungan dan bantuan dari masyarakat dalam pengembangan dan pelaksanaan program pendidikan.

Sedangkan dari kepentingan masyarakat tujuannya, yaitu:

1. Memajukan dan meningkatkan kesejahteraan masyarakat terutama dalam moral dan spiritual

2. Memperoleh batuan lembaga pendidikan untuk memecahkan berbagai masalah yang dihadapi masyarakat

3. Menjamin relevansi program lembaga pendidikan dengan kebutuhan masyarakat 
4. Memperoleh anggota masyarakat yang meningkat kemampuannya (Mulyono, 2008:211-212).

Dilihat dari tujuannya maka keberadaan bidang Humas harus diperhitung oleh lembaga pendidikan agar masyarakat dan lembaga pendidikan memiliki hubungan yang saling terkait melalui komunikasi yang baik antara kedua belah pihak. Bagaimanapun masyarakat tidak bisa dipisahkan dari dunia pendidikan karena masyarakat inilah yang penjadi subjek sekaligus objek dalam dunia pendidikan, begitupun lembaga pendidikan adalah harapan bagi masyarakat untuk dapat mengembangkan kemampuan dan akhlaknya.

\section{Catatan Akhir}

Hubungan yang baik akan terjalin apabila fungsi manajemen pada lembaga pendidikan dilaksanakan sebagaimana mestinya, untuk merealisasikan ini semua tentu bidang humas memiliki peran aktif tanpa mengesampingkan peran bagi bidangbidang lain, berjalan bersama dalam mendidik generasi agar menjadi manusia yang berkualitas. Tujuan baik proses pendidikan tidak akan berjalan tanpa dukungan berbagai pihak luar yaitu masyarakat yang menjadi objek proses pendidikan, masyarakat sudah seharusnya memiliki rasa peduli terhadap keberadaan lembaga pendidikan dan mau terlibat di dalamnya dalam memberikan dukungan fisik, psikis dan materi demi terlaksananya proses pendidikan yang diharapkan.

Keterlibatan masyarakat untuk mengawasi lembaga pendidikan ini menjadi acuan semangat bagi lembaga pendidikan untuk terus memperbaiki kualitas pendidikannya, karena bagaimanapun proses pendidikan itu tidak hanya terjadi di lembaga pendidikan tetapi di lingkungan keluarga dan masyarakatlah yang lebih dominan.

Merosotnya akhlak generasi sekarang karena kurangnya kerjasama berbagai pihak dalam mengontrol perkembangan generasi, fakta sosial yang terjadi bahwa walaupun generasi sudah dididik dengan maksimal di lembaga pendidikan tidak menjamin dia akan berperilaku baik di lingkungan masyarakat, bisa saja lingkungannya adalah wahana kebebasannya baginya sehingga muncul masalahmasalah sosial yang tidak diinginkan seperti narkoba, miras, kriminalisasi dan sebagainya. Masyarakatlah yang bertanggungjawab dalam mengawasi perkembangan 
generasi di luar jam sekolah melalui kegiatan dan kemauan yang kuat yang sudah direncanakan oleh pihak sekolah dan masyarakat.

\section{Daftar Rujukan}

Abdul Hadis dan Nurhayati. 2010. Manajemen Mutu Pendidikan. Alfabeta: Bandung.

Maisyaroh. 2011. Maksimalisasi Peran Masyarakat dalam Penyelenggaraan Pendidikan. Tesis Manajemen Pendidikan Islam UIN Maliki Malang.

Mulyono. 2008. Manajemen Administrasi dan Organisasi Pendidikan. Ar-Ruzz Media: Jogjakarta.

Sri Minarti. 2011. Manajemen Sekolah Mengelola Lembaga Pendidikan secara Mandiri. ArRuzz Media: Jogjakarta.

Tim Dosen Administrasi Pendidikan UPI. 2009. Manajemen Pendidikan. Alfabeta: Bandung 